\title{
PRELIMINARY PHYTOCHEMICAL SCREENING AND ANTIMICROBIAL EVALUATION OF THREE MEDICINAL PLANTS USED IN NIGERIA.
}

\author{
Haruna Baba*1 and Adebola Onanuga ${ }^{2}$ \\ ${ }^{1}$ Department of Pharmaceutical and Medicinal Chemistry, ${ }^{2}$ Department of Pharmaceutical microbiology \\ and Biotechnology, Faculty of Pharmacy, Niger Delta University. Wilberforce Island, Nigeria. \\ *E-mail: babharun@yahoo.co.uk
}

\begin{abstract}
Methanol extract of three Nigerian medicinal plants were screened for antimicrobial activity using modified KirbyBauer disc diffusion and agar dilution techniques to determine the diameters of zone of inhibition and minimum inhibitory concentrations (MIC) of the extracts respectively. The extract of each of the plants were tested against five clinical bacterial isolates comprising of two Gram-positive bacteria (Bacillus subtilis and Staphylococcus aureus) and three Gram-negative bacteria (Pseudomonas aeruginosa, Escherichia coli and Klebsiella pneumonia) organisms. All the extracts exhibited moderate to high level of antimicrobial activities against these microorganisms. Phytochemical screening of powdered plant material revealed the presence of some secondary metabolites such as alkaloids, saponins, tannins, anthraquinones and flavonoids. These Nigerian medicinal plants could be developed into cheap, safe and culturally acceptable standardized herbal products and may serve as a source of new molecules for broad-spectrum antimicrobial agents.
\end{abstract}

Key words: Dissotis rotundifolia, Costus lucanusianus, Solenostemon monostachys, Methanol extract, Antimicrobial activity

\section{Introduction}

Plants form an integral part in traditional medicinal practices in all cultures worldwide and a sizeable portion of the world population uses plant for prevention and management of different kinds of ailments. The rural population in particular who do not have access to primary health care, either as a result of non-availability or inability to afford it depends solely on plant remedies for their health problems (Johanna et al 2005). Many of the plants used in ethnomedicine have been found to contain useful therapeutic substances and a good number of them have found their way into orthodox medical practice. For instance, morphine, digoxine, quinine etc which are very useful drugs commonly prescribed by clinicians until date are derived from plants. The search for new compounds which can be useful in the management of diseases that have defied current therapeutic options focuses majorly on plants as a reliable source of lead substances (Kong et al 2003). The high incidence of résistance organisms has made it mandatory for a continuous search for a more potent and safe therapeutic agents. Many plants, which are used in ethnomedicine, have shown promising activity against a host of disease causing microorganisms and they have been documented. Dissotis rotundifolia, Costus lucanusianus, Solenostemon monostachys are medicinal plants used for the prevention and management of different kinds of disease conditions in Nigeria and some countries in West African sub region.

Dissotis rotundifolia Triana, (Melastomataceae), which is one of the 140 species in the genus Dissotis is a native of tropical West Africa (Loigier, 1994; Wagner et al., 1990) and common names include Pink lady (English), Ebafo (Bini), and Awede (Yoruba). It is a versatile perennial slender creeping herb with prostate or ascending stems up to $40 \mathrm{~cm}$ high, rooting at the nodes and producing from seeds and stolons (Abere et al 2009). Traditionally, in various parts of tropical Africa, it has various uses. In Nigeria, the plant is used mainly for the treatment of rheumatism and painful swellings, and the leaves decoction is used to relieve stomach ache, diarrhoea, dysentery, cough, stop abortion, conjunctivitis, circulatory problems and veneral diseases. It is used in East Africa for the treatment of bilharzias (Kokwaro, 1976), and in Cameroun, the leaves are used for dysentery (Noumi and Yomi, 2001).

Costus lucanusianus J. Braun \& K. Schum (Costaceae) is an herbaceous plant of the forested areas of Africa. It is well known in the southern Ivory Coast for its antiabortive activities (Sawadogo, 1986). Indeed, the juice of the stem has been shown to exhibit tocolytic activity (Komenan, 1986; Foungbe et al., 1987).

The Lamiaceae are mostly herbs or shrubs comprising about 200 genera and 3,200 species, commonly with aromatic, herbage, quadrangular stems, and verticillate inflorescences. The leaves are opposite or whorled, and are simple or occasionally pinnately compound S.monostachys is repotedly used in the treatment of type II diabetes, tuberculosis and magagement of treatened abortion (Erah , et al 1996; Idu et al 2006 and Folu. et al 2009). 


\section{Materials and Methods Plant materials}

The Plants were collected in Ugbowo area of Benin City, South- South Nigeria between January and June 2009. Documented folklore use and oral information from the residents formed the basis for the selection of the parts of the plants collected and tested. The authentication of the plant material was done by Dr. B.A. Ayinde of the Department of Pharmacognosy, Faculty of Pharmacy, University of Benin. The voucher specimen numbers for S. monostachys, D. rotundifolia and C. lucanusianus are 1023, 1143 and1098 respetively.

\section{Phytochemical screening}

The powdered material of the plants were subjected to different kinds of chemical tests to investigate the presence of secondary metabolites such as saponins, tannins, flavonoids anthraquinones cyanogenic glycosides, cardiac glycosides and alkaloids using standard procedures (Evans, 1996; Brain and Turner, 1975;Ciulei, 1981; Harborne, 1992).

\section{Preparation of the extracts}

The air-dried plant materials were pulverized into fine powder. A weighed portion (200g) of each of the plant powder was extracted with aqueous methanol by cold maceration for 48 hours. The extracts were filtered and the solvent removed at low temperature $\left(40-45^{0} \mathrm{C}\right)$. Stock solutions of $100 \mathrm{mg} / \mathrm{mL}$ and $400 \mathrm{mg} / \mathrm{mL}$ were prepared for the disc agar diffusion and micro dilution broth assays respectively.

\section{Antimicrobial Screening of Plants' Extracts Agar diffusion method (zone of inhibition measurement)}

Five clinical bacterial isolates (Bacillus subtilis, Staphylococcus aureus, Pseudomonas aeruginosa, Escherichia coli and Klebsiella pneumonia) were obtained from the microbial bank of department of Pharmaceutical Microbiology and Biotechnology, Faculty of Pharmacy Niger Delta University, Wilberforce Island, Nigeria; for the antimicrobial screening of the plants' extracts. The bacterial isolates were standardized using colony suspension method and matching the strain's suspension with 0.5 McFarland standard to give a resultant concentration of $1.5 \times 10^{8} \mathrm{cfu} / \mathrm{ml}$. The antibiotic susceptibility testing was determined using the modified Kirby-Bauer diffusion technique by swabbing the Mueller-Hinton agar (MHA) (Oxoids U.K) plates with the resultant saline suspension of each strain and six wells were made in the agar with aid of cork borer (No. 4, the diameter of the borer is $6 \mathrm{~mm}$ ). The wells were sealed at the bottom with molten sterilized agar, $0.1 \mathrm{ml}$ and $0.2 \mathrm{ml}$ of each of the plants extract representing $10 \mathrm{mg} / \mathrm{ml}$, and $20 \mathrm{mg} / \mathrm{ml}$ respectively were aseptically dispensed into the labeled wells while antibiotic disc (ciprofloxacin $5 \mu \mathrm{g}$ ) used as control was placed on the agar aseptically. The plates were then incubated at $37^{\circ} \mathrm{C}$ for 24 hours. The zone diameters of inhibition produced by each concentration of the plants extracts and that of the antibiotic disc was measured and recorded (CLSI, 2008).

\section{Agar dilution method (MIC measurement)}

Each of the plants extracts was used to prepare Mueller-Hinton agar plates of varying concentrations from $5 \mathrm{mg} / \mathrm{ml}$ to $40 \mathrm{mg} / \mathrm{ml}$ and the plates were all spot-inoculated with each organism's standardized suspension and incubated for growth at $37^{\circ} \mathrm{C}$ for $24 \mathrm{~h}$. The plates that showed no growth were observed, while those with lowest inhibitory concentrations were taken as the minimum inhibitory concentrations (MIC) of the extract (mg/ml) against each tested organisms (CLSI, 2008).

\section{Results}

The methanol extracts of the three plants showed considerable antimicrobial activities at concentration of $20 \mathrm{mg} / \mathrm{ml}$ against most of the tested organisms (Table 2). Their antimicrobial activities were comparable to the standard antibiotic (ciprofloxacin $5 \mu \mathrm{g}$ ) used. The minimum inhibitory concentration (MIC) of the plants' extracts showed that the extract of $S$. monostachys exhibited the most antimicrobial activity by its low MIC (5mg/ml to 20mg/ml) on all the tested organisms (Table 3). The phytochemical screening (Table 1) indicates the presence of secondary metabolites such as Tannins, Flavonoids, Saponins, Anthraquinones, Alkaloids. 
Baba and Onanuga Afr J Tradit Complement Altern Med. (2011) 8(4):387 - 390

Table 1: Phytochemical Screening of the Powdered Plant Material

\begin{tabular}{|l|c|c|c|}
\hline Constituents & S. monostachys & D. rotundifolia & C. lucanusianus \\
\hline Alkaloids & - & + & - \\
\hline Glycosides & + & + & + \\
\hline Flavonoids & + & - & - \\
\hline Tannins & + & - & + \\
\hline Saponins & + & + & + \\
\hline Anthraquinones & + & - & - \\
\hline
\end{tabular}

+ Present

- $\quad$ Absent

Table 2. Zone diameter of Inhibition (mm) of the Methanol extracts of C. lucanusianus, D. rotundifolia and S. monostachys against five selected organisms

\begin{tabular}{|l|l|l|l|l|l|l|l|}
\hline \multirow{4}{*}{ Organisms } & \multicolumn{6}{|l|}{ The Diameter of Zone of Inhibition of Plants Extracts (mm) } \\
\cline { 2 - 8 } & $\begin{array}{l}\text { C. lucanusianus } \\
\text { Concn. (mg/ml) }\end{array}$ & $\begin{array}{l}\text { D. rotundifolia } \\
\text { Concn. }(\mathrm{mg} / \mathrm{ml})\end{array}$ & $\begin{array}{l}\text { S. monostachys } \\
\text { Concn. (mg/ml) }\end{array}$ & $\begin{array}{l}\text { Control } \\
\text { (ciprofloxacin } 5 \mu \mathrm{\mu g})\end{array}$ \\
\cline { 2 - 9 } & 10 & 20 & 10 & 20 & 10 & 20 & \\
\hline B. subtilis & - & $\mathbf{1 2}$ & - & - & - & $\mathbf{1 6}$ & $\mathbf{1 2}$ \\
\hline S. aureus & - & $\mathbf{9}$ & $\mathbf{1 3}$ & $\mathbf{1 6}$ & $\mathbf{2 4}$ & $\mathbf{2 6}$ & $\mathbf{1 5}$ \\
\hline Ps. aeruginosa & - & $\mathbf{1 4}$ & - & $\mathbf{1 1}$ & - & $\mathbf{1 5}$ & $\mathbf{2 3}$ \\
\hline E. coli & - & $\mathbf{9}$ & - & $\mathbf{1 2}$ & - & $\mathbf{1 1}$ & $\mathbf{2 1}$ \\
\hline K. pneumonia & - & - & - & $\mathbf{1 1}$ & - & $\mathbf{1 3}$ & - \\
\hline
\end{tabular}

- No activity

Table 3: Minimum Inhibitory Concentration (MIC) in $\mathrm{mgml}^{-1}$ of the Methanol extracts of C. lucanusianus, D. rotundifolia and S. monostachys against five selected organisms

\begin{tabular}{|l|c|c|c|}
\hline \multirow{2}{*}{ Organisms } & \multicolumn{3}{|l|}{ The MIC of the Plants' Extracts (mg/ml) } \\
\cline { 2 - 4 } & C. lucanusianus & D. rotundifolia & S. monostachys \\
\hline B. subtilis & 15 & $>30$ & 15 \\
\hline S. aureus & 30 & 30 & 20 \\
\hline P. aeruginosa & 20 & 30 & 20 \\
\hline E. coli & 30 & $>30$ & 20 \\
\hline K. pneumonia & - & $>30$ & 5 \\
\hline
\end{tabular}

\section{Discussion}

The three methanol extracts generally exhibited antimicrobial activities on all the tested organisms at concentration of $20 \mathrm{mg} / \mathrm{ml}$. Ekundayo and Ezeogu (2006) reported a weak antimicrobial activity of the dichloromethane and methanol extract of the aerial part of $S$. monostachys. In our study reported here, the methanol extract of the leaves of $S$. monostachys exhibited the most pronounced activity on the Gram-positive organisms (Bacillus subtilis and Staphylococcus aureus) by its wide zone diameter of inhibition and low minimum inhibitory concentration. The reasons for the discrepancy in their report and our own are; the aerial part of the plant which they used comprises of the stem and leaves; if the activity resides only in the leaves, the stem which may not have any activity would weaken the activity of the leaves. Secondly, they extracted the plant material with dichloromethane and methanol in succession thus distributing the active principles into the dichloromethane and methanol; if the active compounds act in synergy, the extraction process would weaken the activity. S. monostachys showed greater activity against the tested microorganism compared with the other plants. The control antibiotic (ciprofloxacin- a broad-spectrum antibiotic) had very little significant activity against these strains of bacteria. The presence of copious amounts of Tannins and Flavonoids in $S$. monostachys is responsible for the high antimicrobial activity (Scalbert, 1991). The result justifies the use of these plants in traditional medicine for the treatment of various kinds of diseases including infectious disease (Idu et al., 2006).

S. monostachys' extract could be a possible choice of treatment of infections caused by resistant strains of Grampositive bacteria especially Bacillus subtilis and Staphylococcus aureus, which other known antimicrobial agents like ciprofloxacin are not able to treat. 
Baba and Onanuga Afr J Tradit Complement Altern Med. (2011) 8(4):387 - 390

\section{References}

1. Abere T. A., Onwukaeme D.N. and Eboka C.J. (2009) Pharmacognostic evaluation of the leaves of Dissotis rotundifolia Triana (Melastomataceae) African Journal of Biotechnology Vol. 8 (1), pp. 113-115

2. $\quad$ Augustin Scalbert( 1991) Antimicrobial properties of tannins . Phytochemistry, 30 (12): 3875-3883.

3. Brain KR, Turner TD (1975). Practical evaluation of phytopharmaceuticals. Wright - Scientechnica, Bristol. 1st Ed. 144.

4. Ciulei I (1981). Methodology for analysis of vegetable drugs. United Nations Industrial Development Organisation. Romania, pp.17-25.

5. Clinical and Laboratory Standard Institute (CLSI) (2008). Performance standards for Antimicrobial Susceptibility Testing Eighteenth informational supplement. M100-S18 28(1): 34-52

6. Ekundayo EO and Ezeogu LI (2006). Evaluation of antimicrobial activities of extracts of five plants used in traditional medicine in Nigeria; International journal of Tropical Medicine 1(2): 93-96

7. Erah, PO. Osuide GE and Omogbai EKI. (1996). Hypoglycaemic Effect of the Extract of Solenostemon Monostachys (P. Beauv) Leaves J. West Afr. Pharm.10 (2) 21-27

8. $\quad$ Evans WC (1996). Trease and Evans Pharmacognosy. WB Saunders Ltd. London. 14th Ed. 119-159.

9. Folu MDO, Oyomoare LE and Marilyn U (2009) Plants used for female reproductive health care in Oredo local government area, Nigeria. Scientific Research and Essay Vol. 4 (3), pp. 120-130

10. Foungbe, S., Sawadogo, D. and Deame, C. (1987) Etude expkrimentale de I'activid uterorelaxante de Alstonia boonei (Apocynacees) et Costus lucunusianus (Zingiberacees) utihdes traditionnallement en CBte d'Ivoire comme antiabortifs. Annalespharmaceutiques Francaises 45, 373-377.

11. Harborne JB (1992). Phytochemical methods. A guide to modern technique of plant analysis. Chapman and Hill, London, p. 279.

12. Idu M and Ndukwu BC (2006) Studies of plants used in ethnomedicine in Ethiope council Area of Delta state, Nigeria. Research Journal of botany 1(1): 30-43.

13. Johanna K., Harald F., Elfriede P.,Michael H. (2005). Historical and modern plant uses-the example of the Ch'orti'Maya and Ladinos in Eastern Guatemala. Journal of Pharmacy and Pharmacology.57:1127-1152.

14. Kokwaro JC (1976). Medicinal plants of East Africa. General Printers,Nairob, p. 198.

15. Komenan, A.B. (1986) Etude experimenrale comparative de I'activite pharmacologique de I'extrait de Costus lucanusianus (Zingiberucees) et de la rirodrine. Pharmacy thesis, National University of Ivory Coast, 28, pp. 42-93.

16. Kong J.M., Goh N.K., Chia L.S., Chia T.,F. (2003). Recent advances in traditional plant drugs and orchids. Acta Pharmacol Sin 24(1), 7-21

17. Loigier HA (1994). Spermatophyta. Descriptive flora of Puerto Rico and Adjacent islands, pp. 1-3.

18. Noumi E, Yomi A (2001). Medicinal plants used in intestinal diseases in Mbalmayo Region, Fitoterapia, pp. 246-254.

19. Sawadogo, D. (1986) Elude experimentale de lhctivite uterorelaxanle de deux plantes utilisees traditionnellement en Cote d'lvoire comme antiabortifs. Pharmacy thesis, National University of Ivory Coast, 24, pp. 8-10.

20. Wagner WL, Herbst DR, Sohmer SH (1990). Manual of flowering plants of Hawaii. University of Hawaii Press, Bishop Museum, Honolulu, p.210. 